\title{
Muhalefet, Kime ve Neye: Dinsel Söylemde Muhalefet
}

\section{Şinasi GüNDüZ*}

\section{Opposition; to Whom and What? Opposition in Religious}

\section{Discourse}

Citation/C: Gündüz, Şinasi, (2018). Opposition; to Whom and What? Opposition in Religious Discourse, Milel ve Nihal, 15 (2), 8-33.

Abstract: Many governments have tried to legitimate themselves by religious discourse and, by doing this, demanded obedience from the society. However, there have been frequent clashes between religion and religious groups and the ruling class from the past to present. The ruling class has declared every movement that does not obey and acts as opponent unlawful, and has tried to destroy. Religious traditions, on the other hand, take the concept of opposition in two contexts: the first is the opposition to the supreme being/beings of religion and the values it predicts. Religion does not accept such opposition and treats it as a deviation and sin. The latter is the opposition to the earthly authorities. Concerning this each tradition has an understanding due to its concept of authority. Some religions like Christianity bless the concept of sovereignty, predict obedience to any government in earth and criticize opposition. The others like Islam accept God as the absolute authority and the relationship with earthly Powers is addressed in this content. It is consequently considered that every authority that does not receive its reference form God and God's will is null and unlawful. It is also accepted as a duty for every believer to oppose such authorities. The Qur'an, as a matter of fact, gives many examples of the opposition of the prophets to such authorities throughout history.

* Prof. Dr., İstanbul Üniversitesi, İlahiyat Fakültesi, Dinler Tarihi Anabilim Dalı [sigunduz@gmail.com]. 
Atıf/@: Gündüz, Şinasi, (2018). Muhalefet, Kime ve Neye: Dinsel Söylemde Muhalefet, Milel ve Nihal, 15 (2), 8-33.

Öz: Birçok iktidar dinden ve dinin bazı kutsallarından hareketle kendisini meşrulaştırmış ve toplumdan kendilerine itaat istemişlerdir. Bununla birlikte geçmişten günümüze din ve dini gruplarla iktidar sahipleri arasında sıklıkla çatışmalar yaşanmıştır. İktidar kendisine itaat etmeyen ve muhalif davranan her akımı gayrimeşru ilan etmiş ve bir şekilde yok etmeye çalışmıştır. Dini gelenekler muhalefet kavramını iki bağlamda ele alır: bunlardan ilki dinin üstün varlıklarına ve öngördüğü değerlere muhalefettir. Din böylesi bir muhalefeti kabul etmez; sapkınlık ve günah olarak görür. İkincisi ise dünyevi egemenlere yönelik muhalefettir. Bunu ise her din kendi iktidar algısından hareketle tanımlar. Öyle ki egemenliği kutsayan Hıristiyanlık gibi yapılar dünyevi iktidarlara itaati öngörür ve muhalefeti eleştirir. İslam gibi dinler ise mutlak otorite olarak Allah'ı kabul ettiğinden dünyevi iktidarla ilişkiyi bu bağlamda ele alır. Referansını Allah'tan ve Allah'ın sınırlarından almayan her iktidarı zulüm olarak değerlendirir ve böylesi iktidarlara muhalefeti inanan birey için bir görev addeder. Nitekim Kur'an tarih boyu peygamberlerin böylesi otoritelere karşı yaptıkları muhalefetten birçok örnek verir.

Anahtar Kelimeler: muhalefet, otorite, din, dinsel söylem, İslam, Hıristiyanlık.

\section{Giriş: Din ve Muhalefet}

Din, dinsel söylem ve "dindarlar" açısından bakıldığında muhalefet kavramının ne anlam ifade ettiği ve nasıl anlaşıldığı her daim ilgi konusu olmuştur. Bu husus, özellikle dindarlık ve iktidar tartı̧̧malarının gündem oluşturduğu ve "iktidara eklemlenen dindarlar" söyleminin yaygınlaştığı ortamlarda daha bir anlam kazanmıştır. $\mathrm{Bu}$ çalışma günümüzde dindar bireylerin ve grupların itaat ya da muhalefet bağlamında iktidarla ilişkilerini konu alacak değildir. Çalışmada dinde, hassaten İslam ve Hıristiyanlık gibi yapılarda muhalefetin ne'liği ve nasıllığı konusu ele alınacak ve kutsal metinlerden ve din tarihinden hareketle muhalefetin bağlamı üzerinde durulacaktır. Bu çerçevede dinsel öğretide dinin hitap ettiği birey ve toplum için muhalefetin aslolan bir tutum olup olmadığı ve muhalefet etmenin sınırları tartışılacaktır.

Yalnız İslam ve Müslümanlar için değil geçmişten günümüze hemen hemen tüm dini gelenekler bağlamında güç ve otoriteyle ilişkiler doğrudan ya da dolaylı olarak hep gündem oluşturmuştur. Dinin otoriteye/egemenliğe yaklaşımıyla mevcut iktidarlarla ve 
egemen geleneklerle ilişkinin sınırlarının nasıl olması gerektiği hemen her dinin cevaplama durumunda olduğu/kaldığ 1 önemli bir sorunsal olmuştur. Tarihsel süreçte din ve din mensuplarının güç ve iktidarla ilişkileri genelde iniş çıkışlı olmuştur. Öyle ki dini gelenekler ve bağlıları sıklıkla egemen güçlerin baskı ve takibatına maruz kalmış, ancak zaman zaman da şu ya da bu şekilde güç ve iktidarın öznesi haline gelmiş ve iktidara eklemlenme durumunda kalmışlardir.

Günümüzde dünya genelinde farklı din bağlılarının, özellikle de içinde bulunduğumuz coğrafyada Müslüman kimliği taşıyan birçok kesimin adeta gücü kutsayan iktidar algıları ve bu doğrultuda egemen güçlere ve paradigmalara eklemlenmeye yönelik tutum ve tavırları dikkat çekicidir. Dolayısıyla dinin otorite ve egemenlik kavramlarına bakışı ile itaat ve muhalefet kavramları çerçevesinde iktidara yönelik öngördüğü tutumun ne'liği yanında dindar bireylerin ve toplulukların egemen güçlerle ve sistemle ilişkisinde nasıl bir tecrübe ortaya koydukları ve dinin öngördüğü perspektiften hareketle aslında nasıl bir duruşun olması gerektiği çeşitli yönlerden tartışılmaktadır.

Sosyal, siyasal ve kültürel yapılarda güç odaklarıyla ilişkilerin, egemen güçlerce sınırları çizilen yasal olan-olmayan, iyi-kötü ve doğru-yanlış kategorizasyonuna ve bunlara yönelik paradigmalara dair tutumların nasıl olması gerektiği toplumsal yapıda yer alan farklı grupların kategorize edilmesinde belirleyici olmuştur. Kuşkusuz bütün bunlarda temel olan kriter "iktidar/otorite ve itaat" ilişkisidir. Bu ilişkinin ne'liği ve nasıllığı, iktidar açısından bireyin ve toplumun tanımlanmasında belirleyici bir ölçüttür. Bu doğrultuda otoriteye itaat, her dönem muktedirlerince bireye ve topluma biçilen temel rol olmuştur. Birey ve toplum otoritenin kendisine biçtiği, uygun gördüğü bu rol çerçevesinde değerlendirilmektedir: Egemen güçlere ya da bunlarca temsil edilen, belirlenen zihniyete itaat ile tâbi olup kabullenmeyi temsil eden "makbul, meşru" birey ve ahali ile muhalefeti, karşı çıkmayı ve isyanı temsil eden "bozguncu, isyankâr ve gayrimeşru" bireyler ve kesimler şeklinde...

$\mathrm{Bu}$ çerçevede geçmişten günümüze tarihin her döneminde mevcut iktidara/otoriteye ve bunlar tarafindan belirlenen sosyal, siyasal yapıya itaat, otorite tarafından "makbul" sayılan bireyleri ve toplumu üretirken, cârî sistemi ve egemenleri eleştirmek, sorgulamak ya da karşı çıkmak "makbul görülmeyen”, "isyankâr" bireyleri 
ve yapıları ortaya çıkarmıştır. Otorite ve temsil ettiği değerleri sorgulamak, eleştirmek ve karşı çıkmak, tarihin her döneminde hoş karşılanmayan "başkaldırı" eylemleri olarak addedilmiş ve "anarşi" ve "isyan" kavramları bunlar üzerinden tanımlanmaya çalışılmıştır.

İktidara/otoriteye itaat yerine, onu ve temsil ettiği zihniyeti sorgulamak ve karşı çıkmak bireysel ve toplumsal muhalefet kavramını ortaya çıkarmıştır. Karşı çıkmayı, eleştirmeyi hatta başkaldırıyı temsil eden muhalefet ve muhalif olmak, otorite ve itaat ilişkisinde olumsuz bir bağlam taşıdığı için iktidarlar tarafından genelde hoş karşılanmayan bir tutum ve tavır olarak görülmüş ve hatta zaman zaman şeytanlaştırılmıştır. Buna karşılık muhalefet kavramı bazılarınca da her zaman esas alınması gereken bir duruşun ifadesi olarak değerlendirilmiş ve adeta kutsanmıştır.

Genel olarak bakıldığında muhalefet kavramının, iktidara karşı çıkışı oldukça geniş bir yelpazede temsil eden birçok yapıyı bünyesinde bulunduran bir karakteristik arz ettiği görülecektir. Öyle ki iktidara kesin bir karşı çıkış yerine onu ıslah etmeyi ve dönüştürmeyi amaçlayan, iktidarın yanlış yapmasına karşı bir denge sağlama görevine talip olan ve bu doğrultuda ıslahatı ve revizyonizmi önceleyen "yapıc1" muhalefet yanında, iktidarla ve temsil ettiği zihniyetle kesin bir hesaplaşmayı amaçlayıp mevcut otoriter yapıyı tersyüz etmeye çalışan, dolayısıyla da toplumsal yapıda islahatı değil mevcut yapının çözülmesini hedef edinen "yıkıcı" muhalefet de vardır. Bunun yanı sıra yapısı ne olursa olsun her iktidar aygıtına karşı çıkan ve her halükârda muhalefet etmeyi temel misyon edinen "müzmin" muhalefetten de söz edilebilir.

\section{İtaat ve Muhalefet Bağlamında Din ve Siyasal İktidar İlişkileri}

Yukarıda da dikkat çektiğimiz gibi, din ve dini grupların iktidarla ilişkileri açısından yalnızca kendi değerleriyle çelişen/çatışan egemen yapıları sorgulayan ve onlara karşı çıkan dindarlar ve dini gruplar değil, bunun yanında birçok "dindar" bireyin ve dini grubun muktedir yapılara itaati ve onlarla işbirliğini tercih ediyor olması hatta iktidarla özdeşleşmesi tartışma konusudur. Batıdan doğuya dünyanın birçok bölgesinde farklı dini yapılar ve zihniyetler mevcut iktidar yapılanmalarıyla yakın işbirliği içerisindedir. Dini gelenek ve iktidar ilişkisine dayalı bir yapılanma denildiğinde akla mutlaka Vatikan, İsrail ve Suudi Arabistan gibi teokratik devletler ya da adı konulmamış başka teokratik devletler gelmemeli... Amerika Birleşik Devletleri (ABD) örneğinde olduğu gibi belirli dini 
zihniyetlerin iktidarlar üzerinde oldukça etkili olduğu birçok ülke vardır. Örneğin her ne kadar teorik olarak seküler, liberal, demokrat bir kimliği ön plana çıkarsa da ABD'de Evanjelizm ve Siyonizm gibi akımların sosyal ve siyasal işleyişte oldukça etkili olduğu bir vakıadır. ABD'yi “Tanrı ülkesi” ABD'lileri de “Tanrı halkı" olarak tanımlayan ve dini öğretilerinin merkezine "Amerikancılık", "Mesih'in ikinci gelişi”, "yeniden doğuş" ve "evanjelizasyon” gibi kavramları yerleştiren Evanjelizm'in, bugün ABD egemen yapısı üzerinde tartışılmaz bir etkisi vardır. Öyle ki son dönemlerde ABD seçimlerinde yönetime gelen başkanların arkasındaki yüzde 40'lık evanjelik destek bunun bir göstergesidir. Yine Siyonizm'in yalnızca ABD'de değil Batı dünyası genelinde sosyal ve siyasal alanda, özellikle de diş politikada etkili olduğu bilinmektedir. Öyle ki gerek ABD'de gerekse Siyonizm'in etkili olduğu diğer Batı ülkelerinde, özellikle İslam coğrafyasına yönelik dış politikanın İsrail ile ilişkiler bağlamında bir güvenlik politikası çerçevesine oturtulduğu görülmektedir.

İçinde yaşadığımız coğrafyada da kendisini “dindar" addeden bireylerle bunlar tarafından oluşturulan yapıların güç odaklarıyla yakın ilişkileri tartışılmaktadır. Burada tartışma konusu olan şeyler arasında önemli bir husus, dindar bireylerin iktidarlara eklemlenmesi ya da iktidarların kendilerini dindar bireyler üzerinden meşrulaştırma yoluna gitmesidir. Kuşkusuz din, İran ve Suudi Arabistan gibi teorik olarak da belirli bir dini anlayışı devlet yap1lanmasında temel kabul eden ülkelerde önemlidir. Bunun yanında din; laik, liberal ve demokratik yapılanma öngören ülkelerde de bir o kadar önemlidir. Nitekim bu önemi nedeniyle hemen her dönemde bu ülkelerde din politikalarına ayrı bir değer verilmiştir. Örneğin Türkiye, her ne kadar cumhuriyetin kuruluşuyla birlikte laik ve seküler bir devlet yapılanmasını esas alsa da Türkiye'de yürürlüğe konulan laiklik kaba bir tanımla din ve devlet işlerinin birbirinden ayrışmış olduğu ve devletin dine müdahale etmediği Fransa'dakine benzer bir uygulama şeklinde olmamıştır. Tam tersine devletin dine ve dini anlayışa her daim müdahil olduğu, Diyanet İşleri Başkanlığı, İmam-Hatip okulları ve İlahiyat fakülteleri gibi din hizmetlerine ve dini eğitime yönelik kurumları doğrudan kurup, yönettiği ve denetlediği bir laiklik anlayışı tesis etmiştir. Tabi bu anlayış, teorik olarak dinle devletin birbirine müdahil olmadıkları bir laiklik uygulamasından hayli uzaktır. Bu sistem bazı araştırıcılarında vurguladıkları gibi, siyasal otoritenin dini ve din 
anlayışını kontrol altında tutup yönlendirdiği "Sezaropapizm" ya da "Bizantizm" tarzı bir din-devlet ilişkisini ifade etmektedir.

Böylesi toplumlarda her daim siyasal iktidarlar kendi iktidarlarının devamı açısından dini anlayışı kendi bekalarına uygun olacak tarzda yorumlamaya ve dindarları ya da dini grupları kontrol altında tutmaya büyük önem atfetmişlerdir. Bu nedenle laik, seküler, liberal, demokrat ve kapitalist ulus-devlet yapısına uygun rafine bir din/İslam yorumu oluşturulmaya, yerleştirilmeye çalışılmıştır. Yine bu nedenle bu din anlayışını temsil edip halka yayacak "aydın din adamını" yetiştirmek ve istihdam etmek amacıyla çeşitli dini kurumların tesisi sağlanmıştır.

Siyasal otoriteye eklemlenen ve ona itaati dini kimliğiyle özdeşleştiren bu anlayış karşısında, içinde yaşadığımız coğrafyada belirli kesimlerin siyasal yapıya ve iktidar aygıtlarına hep mesafeli durduğu ve fiilen olmasa da zımnen bir karşıtlık ve çatışma içinde olduğu da bilinmektedir. Siyasal otorite, böylesi grupları etkisizleştirmeyi, bu mümkün değilse de bir şekilde dönüştürmeyi ya da bunları da sisteme entegre etmeyi temel bir siyaset olarak benimsemişlerdir. Esasen otoritelerini kabul ve devam ettirmek için egemen güçlerin ve iktidarların din ve dini gruplar üzerinden yürüttükleri bütün bu politikalar, diğer yönden önemli bir kültürel öğe olan dinin birey ve toplum üzerindeki belirleyici etkisine de işaret etmektedir.

İktidar, sosyal ve siyasal işleyişe dair bir egemenlik aygıtı olarak birey ve toplum üzerinde hakikatin ne'liğinin tayini ve bunun nasıl uygulanması gerektiği konusunda kendisini yetkin ve yetkili addeder. Buna benzer şekilde din de hitap ettiği bireye ve topluma hakikatin ve kurtuluşun ne'liği konusunda mesajlar vermeyi ve inanan bireyi ve topluluğu yönlendirmeyi amaçlar. Dolayısıyla din ve siyasal iktidar ilişkisi tarih boyu her daim canlı olmuştur. Bu canlı ilişki siyasal iktidarların dine ve dini gruplara yönelik iki yönlü bir ilişki geliştirmesine yol açmıştır. Bunlardan ilki siyasal iktidarların kendilerini dini kurumlar ya da söylemler aracilığıyla meşrulaştırması ve böylelikle din bağlamındaki bir muhalefetin engellenmesidir. Diğeri ise iktidara karşı çıan, eleştiren, meydan okuyan ya da alternatifler üreten dini algıların ve grupların şeytanlaştırılması, onlara savaş açılması ve yok edilmeye çalışılmasıdır. Bu her iki tutuma da geçmişten günümüze hemen her toplumdan sayısız örnekler verilebilir. 
Tarihte Roma ve Mısır'dan Asur, Babil ve İran'a kadar pek çok kadim coğrafyada iktidarların kendilerini temsil ettikleri dinsel değerlerden hareketle meşrulaştırdıkları bilinmektedir. Eski Mısır ve Roma gibi yapılarda "Firavun" ya da "Sezar" adı verilen yöneticinin kendisiyle metafizik âlem ve ilahi varlıklar arasında bir bağ kurduğu ve iktidarını bu bağdan hareketle pekiştirdiği görülür. Örneğin Eski Mısır'da firavunların tanrı Horus'un yeryüzündeki enkarnasyonu, dolayısıyla tanrıların yeryüzündeki temsilcileri olduklarına inanılır ve onlar "iki âlemin rabbi, efendisi" olarak nitelenirdi. ${ }^{1} \mathrm{Bu}$ nedenledir ki, Hz. Musa ile olan mücadelesinde zamanın firavunu yönetimi altındaki halktan, yaşadıkları âlemin mülkünün kendisine ait olduğunu, kendisinden başka bir ilah edinmemelerini, kendisi izin vermedikçe başka bir ilaha inanmamalarını istemektedir:

Firavun, kavmine seslenerek dedi ki: “Ey kavmim! Misır hükümdarlığı benim değil mi? Şu nehirler de benim altımdan akıyor (değil mi?) Hâlâ görmüyor musunuz? Yoksa ben, şu zavallı, nerede ise maksadını anlatamayacak durumda olan bu adamdan daha hayırlı değil miyim? (Eğer doğru söylüyorsa) ona altın bilezikler atılmalı yahut onunla beraber bulunmak üzere melekler gelmeli değil miydi? Firavun, kavmini küçük düşürdü (ezdi). Onlar da kendisine itaat ettiler. Çünkü onlar yoldan çımış bir toplumdu. (Zuhruf, 5154)

Firavun, “Ey ileri gelenler! Sizin benden başka bir ilâhınız olduğunu bilmiyorum... (Kasas, 38)

Firavun, "Eğer benden başka bir ilâh edinirsen, andolsun seni zindana atılanlardan ederim." (Şuara, 29)

Firavun, “Ben size izin vermeden ona iman ettiniz ha!” dedi. "Şüphesiz bu halkını oradan çıkarmak için şehirde kurduğunuz bir tuzaktır. Göreceksiniz!" (A'raf, 123)

Tıpkı Eski Mısır'da olduğu gibi Roma'da da imparatorlarla ilahi âlem arasında bir irtibat kurulmuş ve imparator Augustus örneğinde olduğu gibi imparatorlar tanrının yeryüzündeki temsilcileri olarak görülmüştür. Nitekim Bergama'da bir mermer büst üzerinde yazılı olan "İmparator Sezar, Tanrı oğlu, tanrı Augustus" ifadesinde olduğu gibi, imparator Augustus için yaygın olarak theou

1 Bk. S.R. Najovits, Egypt, Trunk of the Tree: A Modern Survey of and Ancient Land, Vol. I, Algora Publ., 2003, s. 152 vd. 
hyios (Tanrı oğlu) sıfatı kullanılmıştır. ${ }^{2}$ Eski Yunanlılar Augustus'u yüce Tanrı Zeus ile özdeşleştirmişlerdir. ${ }^{3}$ Bundan başka Eski Roma'da imparatorlar Pontifex Maximus, yani dini kurumun en üst düzeyindeki rahip olarak kabul edilmişlerdir. MÖ 1. yüzyılda Julius Sezar'dan itibaren Roma imparatorları MS 4. yüzyıl sonlarına kadar bu unvanlarını taşımışlardır. ${ }^{4}$

Bu ve benzeri tüm örneklerde dikkat çeken husus; dünyevi otoritenin kendisini bir şekilde ilahi âlemle, ulûhiyetle irtibatlandırması ve böylelikle kendine dini anlamda da bir meşruiyet kazandırıp kendisine ve temsil ettiği düzene karşı muhalefetin engellenmesidir. Böylesi bir yapıda doğal olarak iktidara itaat dini bir bağlam kazanmakta ve dolayısıyla dünyevi yöneticiye itaat tanrıya, tanrı düzenine itaat; ona isyan ise tanrının düzenine isyan olarak addedilmektedir. Nitekim Babil kralı Hammurabi örneğinde olduğu gibi, dünyevi iktidarın yürürlüğe koyduğu yasalara tanrı ya da tanrılar adına itaat istenmektedir. ${ }^{5}$ Buna benzer örnekler tarihin ilerleyen dönemlerinde diğer çeşitli toplumlarda da görülmektedir. Örneğin ortaçağda çeşitli teokratik yönetimlerin tanrı adına yeryüzünde dünyevi bir iktidar kurdukları, İngiltere'deki Anglikanizm örneğinde olduğu gibi Hıristiyanlık içindeki çeşitli milli kiliselerin en üst düzeyde dünyevi iktidarlara bağlı olduğu ya da İslam tarihinde bazı yöneticilerin kendilerini "yeryüzünde Allah'ın gölgesi" şeklinde tanımladıkları bilinmektedir.

Bütün bu ve benzeri yapılarda din ve siyasal iktidar arasındaki ilişkinin temelini, dini kurumların ve dine bağlı ahalinin iktidara itaat etmesi oluşturmuştur. Bu doğrultuda iktidarı ve onun dini alan da dâhil olmak üzere yaptığı tasarrufları sorgulamak "sapkınlık" sayılmıştır. İktidarı ve tasarruflarını sorgulama ya da muhalefet etme, belirli bir dini cemaat ya da din yorumu taraftarları tarafından yapılıyorsa söz konusu grup heretik, yani sapkın, zındık kabul edilmiş ve her türlü takibata tâbi tutulmuştur.

2 R. Helms, Gospel Fictions, New York: Prometheus Books, 1988, s. 25.

3 Horsley, R.A. (ed.), Paul and Empire, Religion and Power in Roman Imperial Society, Trinity Press International, 1997, ss. 22-23.

$4 \quad$ Bk. L. Canfora, Julius Caesar: The Life and Times of the People's Dictator, University of California Press, 2007, s. 23 vd.

5 Örneğin Hammurabi, kendisinin yüce tanrı Marduk tarafından insanları yönetmek üzere görevlendirildiğini ve meşhur hukuk kodeksini yüce güneş tanrısından aldığını söylemektedir. 
Böylelikle toplumsal yapıda hegemonik güce muhalefet, egemen yapılar tarafından heretik ya da heterodoksal addedilen yapıları şekillendirmiştir. Egemenleri ve bunlar tarafından temsil ve icra edilen sosyal, siyasal ve kültürel yapıları ve değerleri sorgulamak ve eleştirmek çoğu zaman sadece eleştiri ve karşı çıkış boyutuyla da kalmamıştır. Heretik ya da sapkın sayılan akımlar, mevcut yapıları sorgulama ve bunlara muhalefet etme yanında, farklı değerlerin ve sosyal yapıların önerilmesi şeklindeki alternatif değerler sisteminin ve yapıların da temsilcisi olmuşlardır. Egemen kültüre karşı alternatifler üreten heterodoksal yapıların ve "heretik" addedilen kesimlerle akımların bu yaklaşımı doğal olarak hegemonik yapılar/güçler tarafından kabul edilecek bir durum değildir. Bu nedenledir ki muhalif kesimler, tarih boyu hoş karşılanmamış, aksine sapkın, isyankâr, bozguncu addedilerek şiddete ve takibata maruz kalmışlardır.

Dinler tarihinde siyasal iktidarın tasarrufu dışında bir yapılanmaya yöneldiği için sapkın ve isyankâr addedilip şiddete maruz kalıp cezalandırılan birçok hareketten söz edilebilir. Hıristiyanlıktan örnek vermek gerekirse, Miladi 4. yüzyılın ilk yarısında Kuzey Afrika' da bağımsız bir kilise yapılanması girişiminde olan Donatusçulara karşı imparatorluğun bir ordu gönderip onları kılıçtan geçirdiği bilinmektedir. Bu olay nedeniyle Donatusçular kendi hareketlerini "şehitler kilisesi" olarak adlandırmıştır. ${ }^{6}$ Bunun yanında yine Hıristiyanlık tarihinde, ana gövde din anlayışına ya da siyasal iktidara muhalif tavrı nedeniyle takibata uğrayan, hatta Haçlı Seferlerine muhatap olan başka birçok akım vardır. Farklı kristolojisiyle 4. yüzyılda aforoz edilip takibata uğrayan Aryüs ve taraftarlarılla 13. yüzyılda kendilerine karşı Haçlı Seferi düzenlenen Albigensler bunlara örnek olarak verilebilir.

Her ne kadar Hıristiyanlık tarihinde ana gövde kilise akımlarına ya da Roma Katolisizmi gibi ortaçă̆ boyunca teokratik bir krallık olarak kendisine dünyevi iktidar alanı oluşturmuş olan yapılara muhalefeti nedeniyle heretik/sapkın addedilen ve takibata uğrayan birçok akım olmuşsa da aslında Hıristiyanlık özü itibarıyla siyasal iradeye itaati önceleyen ve muhalefeti uygun görmeyen bir yapı arz etmektedir. Hıristiyan kutsal kitabı dünyevi iktidarlara yönelik, ya-

6 Donatus ve Donatuscular için bkn. H.J. Hillerbrand, A New History of Christianity, Abingdon Press, 2012, ss. 78-79. 
pısı ne olursa olsun otoritenin/iktidarın meşru olarak görülmesi gerektiğini vurgular. Dolayısıyla din ve dindar birey ile dünyevi otorite arasındaki ilişkinin özünü itaat kavramı oluşturur. Siyasal iktidara muhalefet uygun görülmez. Nitekim Pavlus, Yeni Ahit'te Romalılara mektubunda dünyevi otoriteye itaat etme konusundaki Hıristiyan yaklaşımını şöyle özetler:

Herkes altında bulunduğu yönetime boyun eğsin. Çünkü Tanrıdan olmayan yönetim yoktur; var olanlar Tanrı tarafından kurulmuştur. Bu nedenle yönetime karşı direnen, tanrının düzenlediğine karşı gelmiş olur. Karşı gelenler yargılanırlar. ... yönetim senin iyiliğin için Tanrının hizmetindedir. Ama kötü olanı yaparsan kork. Yönetim, kılıcı boş yere taşımıyor; kötülük yapanın üzerine Tanrının gazabını salacak olan öç alıcı olarak Tanrının hizmetindedir. Bunun için yalnız Tanrının gazabı nedeniyle değil, vicdan nedeniyle de yönetime boyun eğmek gerekir. Vergi ödemenizin nedeni de budur. İşte yöneticiler, Tanrının bu amaç için gayretle çalışan hizmetkârlarıdır. Vergi hakkı olana vergiyi, gümrük hakkı olana gümrüğü, korku hakkı olana korkuyu, saygı hakkı olana saygıyı, herkese hakkını verin. (Romalılara Mektup 13: 1-7)

İktidara itaatin vurgulandığ bu yaklaşımda egemenlik/otorite niteliğinin tanrısal bir nitelik olarak algılandığına dikkat çekilir. Dolayısıyla bu niteliği elinde bulunduran her kurum ya da kişi, elinde bulundurduğu bu tanrısal nitelik sayesinde yönetimini yasal bir zemine dayandırmaktadır. Bu durumda egemen güçlere muhalefet etmek veya onlara itaatsizlik tanrısal bir nitelik olan otoriteye karşı gelmektir. Bu ise Tanrıya karşı gelmekle eşdeğerdir. Yeni Ahit'teki bu yaklaşıma göre otoriteye itaatsizlik durumunda egemen güçlerin kullandığı kılıç, Tanrının gazabının aracıdır. Nitekim Pavlus bu hususta yukarıdaki alıntıda vurgulandığı gibi, yönetimin kılıcı boş yere taşımadığını, bu kılıcın kötülük yapanın üzerine Tanrının gazabını salacak olan öç alıcı olarak Tanrının hizmetinde olduğunu söyler. Bu nedenle dünyevi otoriteye ya da egemen güçlere isyan eden ve dolayısıyla cezalandırılan kimseler, tanrısal düzene karşı çıktıklarından dolayı Tanrının gazabına uğramış olmaktadırlar.

Pavlus'un, egemenliği tanrısal bir nitelik olarak gören ve otoriteyi/egemenliği ikiye ayırarak metafizik boyutuyla Tanrıya sosyalsiyasal-dünyevi boyutuyla da krala/imparatora hasreden bu düşüncesi, Hıristiyan geleneğindeki din-dünya ayrışmasının da temelini oluşturmaktadır. Tanrı, kişi yaşamındaki inanç ve cemaat (kilise) içi 
yaşantıyı ifade eden dinsel alana egemen olan üstün güçtür; onun egemenliği kozmolojik ve metafizik bir boyut taşımaktadır. Kral ise yaşamın sosyal-siyasal-kurumsal yönünü ifade eden dünyevi alana egemen bir üstün güçtür. Egemenliğe yönelik bu ikili ayrımla birlikte Hıristiyanlık, Tanrının egemenliğinin yakın bir gelecekte dünyevi alana da yayılacağını ve Mesih'in Krallığı bünyesinde tanrısal egemenliğin tek bir elde, tanrısal Oğul İsa Mesih'te toplanacağını öngörmektedir. Zira Hıristiyanlığa göre Mesih, aslında "her yönetim ve hükümranlığın başıdır" (Koloselilere Mektup 2:10). Ancak bu geçekleşene kadar, dünyevi egemenliği elinde bulunduran yönetimlere itaat tanrısal bir buyruktur. Bu yaklaşım doğrultusunda miladi ilk yüzyıllarda Hıristiyan ilahiyatçılar her fırsatta siyasal otoriteye itaatin asıl olduğunu vurgulamış ve bu otoriteye muhalefeti uygun görmemişlerdir. Bunun tek istisnası, otoritenin inanan bireyi dinden dönmeye zorlamasıdır. Nitekim kendisi de sonunda siyasal otorite tarafından yakılarak ölüme mahkûm edilen İzmir piskoposu Polycarp (MS 69-155), bir Hiristiyanın, inancına saldırılmadıkça ve "imparator Tanrıdır" demeye zorlanmadıkça otoritelere tam bir sadakat ve itaat göstermesi gerektiğini savunmuştur. ${ }^{7}$

Hıristiyan kutsal metninde, tanrısal nitelik olarak görülen egemenlik/iktidar yetisini elinde tutan dünyevi otoriteye itaatin ön plana çıkarılması, MS 4. yüzyıldan itibaren Hıristiyan geleneğine yerleşen ve özellikle Bizans bünyesinde 15. yüzyıla kadar İstanbul Kilisesine hâkim olan "Sezaropapizm" (ya da Sezaropapalizm) anlayışına da zemin oluşturmuştur. İmparator Konstantin tarafından formüle edildiği düşünülen ve bu nedenle "Konstantinianizm" diye de adlandırılan Sezaropapizm, yalnızca dünyevi alanda değil kilise içi yaşantıda da imparatoru mutlak egemen güç olarak kabul etmeyi, dolayısıyla "devlete bağlı din" düşüncesini ön plana çıkaran bir sistemdir. Sezaropapist egemenlik anlayışında kral hem devletin hem de cemaatin/kilisenin başı olarak görülmüştür. ${ }^{8}$ Bizans'ın, kilise içi ve dışı egemenliği imparatorda toplayan Sezaropapist otorite anlayışına karşılık, Roma kilisesinde ise MS 5. yüzyılda Batı Roma'nın yıkılışından itibaren Papalık kurumu hem dünyevi hem de

O. Cullmann, The Early Church, London: SCM Press, 1956, s. 200.

8 Bkn. Hinson, E.G., "Constantinianism", Encyclopedia of Religion, (second edition), ed. L. Jones, Thomson Gale, 2005, c. 3, s. 1967 vd. 
kilise içi tek egemen güç olmaya başlamıştır. Nitekim Roma kilisesinin bütün egemenliği tek elde, kendisinde toplama temayülü, ilerleyen dönemde teokrasi ile sonuçlanmıştır.

Reformasyon dönemi ilahiyatçılarınca eleştiri konusu yapıldığı gibi, Latin kilisesinin bu konumu, Hıristiyan kutsal metninde öngörülen iktidar ve egemenlik anlayışına muhaliftir bir gelişimdir. Zira yukarıda da belirtildiği gibi, Yeni Ahit metinleri, Mesih'in Krallığ döneminde tanrısal otoritenin tek başına yeryüzüne egemen olacağ1 döneme kadar, dünyevi egemenliğin imparator ve kralların elinde bulunduğunu ve onlara itaatin şart olduğunu belirtmiş, tanrısal egemenliğin ise kozmolojik ve metafizik boyutuna dikkat çekmiştir. Oysa teokrasi döneminde Latin (Roma) kilisesi, bu yaklaşımın aksine egemenlik yetkisini her alanda kendisinde toplamıştır. Bu durum kabaca 17. yüzyıla kadar devam etmiştir. Reformasyon dönemi sonrası, özellikle 17. yüzyıl sonlarından itibaren Batıda Aydınlanma dönemi olarak adlandırılan dönemde Batı dünyasında hızla gelişen kilise karşıtı söylemlerin de etkisiyle, kilise kendisini gözden geçirmek durumunda kalmış ve günümüzde yeniden asli konumuna dönerek dünyevi egemenliği laik iktidarlara bırakmıştır. Kilisenin bu yaklaşımı, E. Mortimer'in yerinde tespitiyle "Hıristiyanlığın asli doktrinine geri dönmek" olarak açıklanabilir.9

Peki, otoriteyle/iktidarla ilişkiler bağlamında Hıristiyan kutsal metninin bu perspektifine karşılık İslam'ın kutsal metni Kur'an nasil bir perspektif ortaya koyar? Kur'an egemenlik/otorite anlay1şında Hıristiyanlığın yaptığı gibi egemenliği ilahi ve dünyevi egemenlik alanı şeklinde bir ayrıştırmaya gitmez. Mülkün tek sahibinin Allah olduğunu, her şeyin O'nun kudret, irade ve ilminin eseri olduğunu ve hâkimiyetin yalnızca O'na ait olduğunu burgular. Buna göre yegâne ulûhiyet ve rubûbiyet mercii Allah'tır; her konuda Allah mutlak otorite ve güç sahibidir. Yalnızca insanlar değil kâinattaki tüm varlık Allah'ın emirlerine kayıtsız şartsız riayet etmekle yükümlüdürler.

Kur'an, bu mesajın vurgulanması bağlamında tarih boyu gönderilen peygamberler arasında bir mesaj birlikteliğine dikkat çeker. Kur'an' da yer alan peygamber kıssalarında sıkça otorite ve egemen-

9 E. Mortimer, Faith and Power: The Politics of Islam, London: Faber and Faber, 1982, s. 33. 
lik yetisinin en üst düzeyde sadece Allah'ta olduğu vurgulanır. Esasen dinin/İslam'ın temeli olan lâ ilâhe illallah öğretisinin özü de bu mesajdır. "Hüküm, hükümranlık ancak Allah'ındır", "Allah hâkimler hâkimi değil midir?", "yerde ve göklerde olan her şeyin maliki sahibi Allah'tır" gibi vurgularla Allah'ın mutlak hüküm sahibi olduğu ve her şeyin O'nun kudret ve iradesi altında olduğu vurgulanir:

De ki: "Ey mülkün sahibi olan Allah'ım! Sen mülkü dilediğine verirsin. Dilediğinden de mülkü çeker alırsın. Dilediğini aziz edersin, dilediğini zelil edersin. Hayır, senin elindedir. Şüphesiz sen her şeye hakkıyla gücü yetensin." (Al-i İmran, 26)

Dolayısıyla İslam, itaatin mutlak merciinin ancak Allah olduğunu ve Allah tarafından emredildiği için Allah Resulüne itaat edilmesi gerektiğine vurgu yapar. Yeryüzündeki iktidarlar konusunda ise "sizden olan emir sahiplerine itaat edin" diyerek, dünyevi iktidarlara itaatte bir sınırlama yapar. Bu sınırlama dünyevi iktidarların her türlü tasarruflarında Allah'a ve Resulüne itaati öncelemeleri onlara muhalefet etmemeleridir. Nitekim bu nedenle erken dönem İslam tarihinde Hz. Ebubekir ve Hz. Ömer gibi râşit halifeler halktan, Allah'a ve Resulüne itaat ettikleri sürece kendilerine itaat edilmesini talep etmişlerdir. Buna rağmen ilerleyen İslam tarihinde İslam toplumları içinde oluşan birçok iktidarın bu çizgiden ayrılmış olduğu ve bir çeşit teokratik ya da Sezaropapist tarzında iktidarlar tesis ettikleri de bir vakıadır.

Ayrıca Kur'an, tevhid mücadelesi yürüten peygamberlerin içinde yaşadıkları toplumlarda iktidarlarla/güçlülerle yaptıkları mücadelelerden sıkça örnekler verir. İçinde yaşadı̆̆ı toplumsal yapıda tevhid akidesine aykırı mevcut geleneği sorgulayan her peygamber güç odaklarının şiddetli muhalefetiyle karşılaşmıştır. Buna rağmen onlar, şirke, zulme ve ifsada dayalı cari yapılara yönelik eleştiriden ve bireyle toplumsal yapının tevhid mesajı doğrultusunda inşa edilmesi davasından ödün vermemişlerdir.

Kur'an'a göre peygamberlerin toplumsal yapıda eleştirdikleri, muhalefet ettikleri ve değişmesi için mücadele ettikleri en temel husus; Allah'ın iradesine aykırı olan egemenlik, otorite ve iktidar anlayışıdır. Allah'ı, ulûhiyetin ve rubûbiyetin yegâne mercii olarak kabul etmeyen, Allah'a rağmen, ya da Allah'la birlikte başka birtakım egemenler, otoriteler kabul eden zihniyetler ve bunların yürürlükte olduğu sosyal yapılar, peygamberlerce şirk, zulüm, fesat ve 
fitne kaynakları olarak tanımlanmış ve bunlara karşı mücadele edilmiştir. Peygamberler, otorite ve itaat ilişkisi bağlamında otoritenin yegâne kaynağının Allah olduğunu, dolayısıyla temelde Allah'a itaatin dikkate alınması gerektiğini vurgulamıştır. Allah'a itaatin ise O'nun kitabına ve peygamberlerine itaatle gerçekleşeceğinin altını çizmişlerdir. Bu nedenledir ki Allah'ın kitabını insanlara tebliğ ve tebyîn eden her peygamber insanlardan kendisine de itaat ve ittibâ talep etmiştir. ${ }^{10}$ Peygamberler tüm inanç, düşünce, tavır tutum ve sosyal yapılanmanın Allah'tan başka hiçbir üstün gücün olmadığ1/kabul edilmemesi mesajından hareketle düzenlenmesi gerektiğini vurgulamış, bununla çelişen çatışan her şeyi reddetmişlerdir. Bu doğrultuda toplumsal işleyişte, referansını Allah'tan almayan, ya da Allah'a dayandırılmasına rağmen gerçekte Allah'ın iradesine aykırı olan her şeye karşı çıkmışlardır.

Peygamberler, referansını Allah'tan, Allah'ın iradesinden almayan her yapının sadece şirk, zulüm ve bozgunculuk çıkardığını vurgulamışlardır. Buna karşılık, içinde yaşadıkları toplumsal yapıdaki egemenler ise peygamberin ve temsil ettiği değerlerin bir bütün olarak kendi sistemlerine tehditten başka bir şey içermediğini düşünmüşlerdir. Nitekim bu nedenle olsa gerektir ki yaşadığı dönemde toplumu ahlaksızlık yapmama konusunda uyaran Hz. Lut, alay edilerek "fazla temiz kalmaya çalışmakla" itham edilmiş ve şehirden çıkarılmakla korkutulmuştur. ${ }^{11}$ Benzer şekilde, yalnız Allah'1 üstün güç, ilah edinmelerini, adaleti, ölçüyü tartıyı eksiksiz yapmalarını söyleyen Hz. Şuayb'a karşı çıkarlarken "bunu sana namazın mı emrediyor?" (Hud, 84-87) şeklinde itiraz etmişlerdir. Burada hitap ettiği halkın, Hz. Şuayb'ın namazıyla tebliğ ettiği öğretiler arasında doğrudan bir irtibat kuruyor olması çarpıcıdır. Peygambere muhalefet eden kesim, bununla, Peygamberin tüm söz ve pratiklerini kendi sistemlerine bir başkaldırı olarak değerlendirdiğini, dolayısıyla peygamberin kıldığı namazla tebliğ ettiği hususlar arasında yakın bir birliktelik gördüğünü ortaya koymaktadır.

İçinde yaşadıkları toplumsal yapı, peygamberlerin öğretilerini sahip oldukları geleneğe, atalarından tevarüs ettikleri anlayışa ve düzene aykırı görmüş ve bu nedenle sıklıkla peygamberler, ataların yolundan sapmakla ve saptırmaya çalışmakla itham edilmişlerdir.

10 “Öyle ise Allah'a karşı gelmekten sakının ve bana itaat edin !” Şuara, 144.

11 Bkn. A'râf, 82; Neml, 56. 
Mevcut geleneklerini, atalardan tevarüs ettikleri düşüncesiyle muhafaza ettiklerini vurgulamışlar ve peygamberlerin öğretilerine bu geleneğe aykırı olduğu gerekçesiyle karşı çıkmışlardır. Böylelikle peygamberlere karşı muhalefette "atalar kültü", Kur'an'ın "cahiliye" adını verdiği hakikate karşı aymazlığın en temel dayanağı olmuştur:

... "ama biz babalarımızı böyle yaparken bulduk" dediler (Şuara, 74).

... “Şimdi babalarımızın taptıklarına tapmamızı bize yasakl1yor musun? Şüphesiz, biz senin bizi çağırdığın şeyden derin bir şüphe içindeyiz" (Hud, 62).

"Onlara, "Allah'ın indirdiğine uyun!" denildiğinde, "Hayır, biz, atalarımızı üzerinde bulduğumuz (yol)a uyarız!" derler. Peki ama, ataları bir şey anlamayan, doğru yolu bulamayan kimseler olsalar da mı?" (Bakara, 170)

Cahiliye toplumu bununla, atalar kültünün kendileri açısından temel alınan bağlayıcı bir referans kaynağı olduğunun altını çizmiştir. Buna karşı peygamberler, referansını Allah'ın iradesinden almayan bu yapıları reddetmişler ve atalar kültüne karşı çıkmışlardır. Toplumda nesiller boyu süregelen batılın, zulmün ve ifsadın sapkınlık olduğunu vurgulamış, mevcut sapkın halk gibi bu yapıyı aktaran ataların da sapkın olduğuna dikkat çekmişlerdir.

... "Allah'ın, haklarında hiçbir delil indirmediği, yalnızca sizin ve babalarınızın uydurduğu birtakım isimler (düzmece ilahlar) hakkında mı benimle tartışıyorsunuz? " (A'raf, 71).

İbrahim, "andolsun, siz de atalarınız da apaçık bir sapıklık içindesiniz" dedi (Enbiya, 54).

\section{Din Dilinde Muhalefet}

"Muhalefet" kelimesi din dilinde ve dinsel söylemde önemli bir kavramsal anlam kazanmıştır. Şöyle ki; din dilinde iki tür muhalefetin varlığından söz edilebilir. Bunlardan ilki; dinin temsil ettiği değerlere ve hakikate muhalif küfür, şirk, zulüm, fısk, tuğyan ve benzeri kavramlarla ifade edilen tutum ve tavirlardır. Kutsal metinlerde hakikate muhalif böylesi tutum ve tavırlar eleştirilir; bunun 
kişiyi ya da toplumu günahkâr hale getireceğinin ve helake götüreceğinin altı çizilir. ${ }^{12}$ Diğeri ise dinin, temsil ettiği değerler ve söylemlerle bireyi ve içinde yaşadığı sosyal yapıyı yönlendirmeye, yeniden inşa etmeye çalışması ve bununla da sıklıkla mevcut algılara, anlayışlara ve kurulu yapılara muhalif bir dili ve duruşu temsil etmesidir. Dolayısıyla her dinsel söylemin şahsında hitap ettiği insanı ve toplumu değiştirmeye, dönüştürmeye çabalayan muhalif bir tutumun varlığı söz konusudur.

Bunlardan ilkiyle yani dinin temsil ettiği değerlere ve hakikate muhalefetle ilgili olarak tüm dinsel gelenekler "günah" kavramına yer vermektedir. En genel anlamiyla günah, dinin kutsal değerlerine (teist dinlerde kutsiyetin en üst düzey ifadesi olan Tanrı'ya) karşı ilgisizlik ve lakaytlıktır. Böylesi bir tutum, yani kutsal değerlere ve bunların gereklerine riayet etmeme ya da bunlara muhalefet, kişiyi "günahkâr" yapar. Örneğin İslam'da kutsiyetin en temel referansı ve kutsallar kutsalı (kuddûs) olan Allah'ın iradesine, koymuş olduğu sınırlara (hudûdullah), dolayısıyla Allah'ın emir ve yasaklarına ilgisiz kalmak, karşı çıkmak, düşünce, inanç, tutum ve tavırlarla bunlara muhalefet etmek günahtır. Bu günah; işlenen günahın durumuna göre kişiyi zalim, fasık, mücrim, kâfir ve münafık statüsüne sokar. Böyle bir statü ise imanla bağdaşmaz.

Kur'an, Allah'ın iradesine muhalefetin prototipi olarak İblis karakterine dikkat çeker. Yaratılışı sonrası insanın diğer varlıklar arasındaki konumuna/yerine dair Allah'ın emrine muhalefet İblis'i şeytanlaştırmıştır. Allah'ın, "Âdem'e secde edin” emrine tüm melekler riayet ederken İblis bundan kaçınmıştır:

Hani meleklere, "Âdem'e secde edin" demiştik de İblis hariç bütün melekler secde etmişler, İblis (bundan) kaçınmış, büyüklük taslamış ve kâfirlerden olmuştu (Bakara, 34).

Buna göre İblis'in, Allah'ın emrine riayetsizliği, büyüklenmesinin ve kibirlenmesinin neticesidir. Kibir ve büyüklük taslamaya dayalı bu riayetsizliğinin gerekçesini açıklarken İblis akıl yürütmekte ve Allah'ın emrine riayetsizliğini meşrulaştırmaya çalışmaktadır:

12 Kuşkusuz dinler dinin temsil ettiği değerlere muhalif bu tutum ve tavırlar arasındaki farklılıkları da gözetir. Örneğin İslam, kişinin işleyeceği günahlar arasında şirki, Allah'ın affetmeyeceği günah olarak niteler. "Şüphesiz Allah, kendisine ortak koşulmasını asla bağışlamaz. Bunun dışında kalan (günah)ları ise dilediği kimseler için bağışlar. Allah'a şirk koşan kimse, şüphesiz büyük bir günah işleyerek iftira etmiş olur." Nisa, 48. 
Allah, "Sana emrettiğim zaman seni secdeden ne alıkoydu?" dedi. (O da) "Ben ondan hayırlıyım. Çünkü beni ateşten yarattın. Onu ise çamurdan yarattın" dedi. Allah, "Şimdi in aşağı oradan. Çünkü senin orada büyüklük taslamak haddine değil! Hemen çık! Çünkü sen aşağılıklardansın" dedi (A'raf, 12-13).

Burada dikkat çeken şey; Allah'ın iradesine karşılık İblis'in kendi iradesini ön plana çıkarmış olmasıdır. Bu nedenle o, Allah tarafından kovulmuş ve aşağılık addedilmiştir. İblis'in, Allah'ın iradesine itaati dışlayan bu tavrı ve tutumu şeytanlaşmadır. $\mathrm{Bu}$ andan itibaren o, artık bir şeytandır. Nitekim İblis'in bu tutumunu, yani Allah'ın otoritesine karşı çıkmayı, Allah'ın iradesine karşılık kendi iradesini ön planda tutmayı yeğleyen insan ya da cin herkes Kur'an'a göre şeytandır. Bu nedenle Kur'an, şeytan terimini zaman zaman çoğul formunda kullanır ve aldatıcı insan ve cin şeytanlarının peygamberlere düşmanlığından bahseder.

İşte böylece biz her Peygambere insan ve cin şeytanlarını düşman kıldık. Bunlar aldatmak için birbirlerine yaldızlı laflar fisıldarlar. Rabbin dileseydi bunu yapamazlardı. O halde onları iftiralarıyla baş başa bırak (En'am, 112).

Kur'an, tüm varlıkların Allah'ın egemenliği, otoritesi altında olduğunu, göklerde ve yerde her ne varsa hepsinin mâlikinin ve sahibinin Allah olduğunu, O'nun izni olmaksızın hiçbir şeyin olamayacağını, her şeyin O'nun kudret, irade ve ilminin eseri olduğunu da vurgular. Bununla tek ilah ve rab olan Allah'ın her şeye hâkim olan yegâne güç olduğunu ve O'na hiçbir şeyin hiçbir şekilde ortak koşulmaması gerektiğini vurgular.

Allah'ın mutlak otorite ve egemenliği altında canlı ve cansız tüm mahlûkatta Allah'a kulluk açısından bir birliktelik vardır ve insanın yaratılış gayesi de budur, yani Allah'a kulluktur. İnkârcı ve müşrik birey, Allah'ın otoritesine dayalı bu tevhidi görmezden gelerek ona nankörlük etmekte ya da başka birtakım şeyleri de Allah'a denk tutmak suretiyle onun ulûhiyetine ve rubûbiyetine muhalefet etmekte, böylelikle haddini aşmakta ve büyük bir günah işlemektedir. 
Allah'a itaat ve emirlerine muhalefet etmeme Resule itaati de gerektirmektedir; zira Allah'ın kitabında Allah Resulüne itaat edenin Allah'a itaat etmiş olacağı vurgulanmaktadır. ${ }^{13}$ Ayrıca Kur'an'da, tarih boyu bütün inananların peygamberlerle ilişkisinin özü itibarıyla bir itaat ve ittibâ (tabi olma) ilişkisi olduğuna dikkat çekilir. Dolayısıyla peygambere muhalefete de şiddetle karşı çıkılır.

Kim, kendisine hidayet (doğru yol) besbelli olduktan sonra peygambere karşı çıkar (muhalefet eder), mü'minlerin yolundan başkasına uyarsa, onu yöneldiği yolda bırakırız ve cehenneme sokarız. Orası ne kötü bir varış yeridir (Nisa, 115).

Diğer dini geleneklerde de dinin temel değerlerine ve hakikat öğretisine muhalefet eleştirilir ve günah olarak addedilir. Örneğin kurtuluşu “Tanrı Oğlu” olarak addettiği İsa Mesih'e iman ile açıklayan Hıristiyanlık, bunun dışında bir kurtuluşun olmadığını vurgular. ${ }^{14}$ Dinin öngördüğ̈u tutum ve davranışlardan uzak olanların da asla kurtuluşa ulaşamayacaklarının altını çizer.

Benliğin işleri açıktır. Bunlar cinsel ahlaksızlık, pislik, sefahat, putperestlik, büyücülük, düşmanlık, çekişme, kıskançlık, öfke, bencil tutkular, ayrılıklar, bölünmeler, çekememezlik, sarhoşluk, çılgınca eğlenceler ve benzeri şeylerdir. Sizi daha önce uyardı̆̆ım gibi yine uyarıyorum, böyle davrananlar Tanrı'nın Egemenliğini miras alamayacaklar (Galatyalılara Mektup 5: 19-21).

Benzer şekilde Yahudilikte de günah kişiyi tanrıdan uzaklaştıran bir durum olarak görülür. En büyük günah Tora'ya yani yasaya riayetsizliktir. Kişinin, dinin öngördüğü 613 yükümlülüğe (mitzvah) riayet etmesi beklenir, buna riayetsizlik ise günah (het, avon ya da peşa) addedilir. ${ }^{15}$

Temsil ettiği hakikat öğretisine karşı çıkmayı günah, haddini aşma ve bozgunculuk olarak gören din, esas itibarıyla insana ve topluma yönelik bir restorasyon ve ihtida mesajı taşımaktadır. Bununla

13 "Kim peygambere itaat ederse, Allah'a itaat etmiş olur. Kim yüz çevirirse (bilsin ki) biz seni onlara bekçi göndermedik." Nisa, 80 .

14 "Tanrı, insanları İsa Mesih'e olan imanlarıyla aklar. Bunu, iman eden herkes için yapar. Hiç ayrım yoktur. Çünkü herkes günah işledi ve Tanrı'nın yüceliğinden yoksun kaldı. İnsanlar, İsa Mesih'te olan kurtuluşla, Tanrı'nın lütfuyla, karşılıksız olarak aklanırlar." Romalılara Mektup 3:22-24.

15 Yahudilikte günah kavramı için bk. Y. Basalel, Yahudilik Ansiklopedisi, İstanbul: Gözlem, 2001, c. 1, s.192 vd. 
o, hitap ettiği zaman ve mekân diliminde kendi hakikat mesajı doğrultusunda insanı ve toplumu dönüştürmeyi hedeflemektedir. Dolayısıyla din, yapısı ve temsil ettiği hakikat ve kurtuluş mesajıyla çelişen zihniyetlere ve bunların temsilcilerine karşı çıkmaktadır. Bu durumda, yapısı gereği bireysel ve toplumsal alandaki yanlışları düzeltmek ve doğruları, hakikati vurgulamak iddiasında olan din, kendi hakikat öğretisine karşı tutum ve tavırları reddederken diğer taraftan kendisi de yapısı itibarıyla bir şeylere muhalefet etmektedir.

Dini öğretilerin temel bağlamı, hak-batıl, doğru-yanlış ve iyikötü ayrışması üzerine temellendirilen inançlar, tutumlar ve davranışlardır. Bunu yaparken din, bireysel ve sosyal yapıda yanlış ve kötü olarak değerlendirdiği şeyleri eleştirmeyi, reddetmeyi ve bunlara karşı çıkmayı, temsil ettiği hakikat ve kurtuluş mesajının bir parçası olarak görür. Bu yönüyle de dinsel geleneklerle hitap ettiği sosyal-kültürel çevre arasında bir karşılaşma/yüzleşme kaçınılmaz olur. Nitekim bu nedenle özellikle ortaya çıktı̆̆ı ilk dönemlerinde dinsel yapılar, zamanın egemen kültürü ve sosyal-siyasal yapısı tarafından genelde hoş karşılanmamış, dinin genel geçer kabullere muhalif söylemleri zamanın egemenlerine ve onlarca temsil edilen popüler kültüre karşı bir meydan okuma olarak değerlendirilmiştir. Bunun sonucu olarak da söz konusu dine ve taraftarlarına karşı bir takibat ve hatta şiddet sıklıkla karşılaşılan bir durum olmuştur.

Genelde yaygın popüler kültüre karşı eleştirel bir bakış içinde olan ve bireyle toplumu değiştirip dönüştürmeye çalışan dine, tarih boyu ilk güçlü tepki egemen sınıftan gelmiştir. Örneğin mevcut $\mathrm{H}_{1}-$ ristiyan kaynaklarında yer alan veriler dikkate alındığında, miladi yılların başlangıç dönemlerinde gerek Hz. Yahya'nın gerekse Hz. İsa'nın mesajlarından en fazla toplumdaki egemen güçler rahatsızlık duyduğu, buna mukabil onlar da yoğun eleştirilerini en fazla onlara yönelttikleri görülecektir. ${ }^{16} \mathrm{Bu}$ kaynaklar, insanları tövbe etmeye ve Allah'ın egemenliğini kabul etmeye çağıran $\mathrm{Hz}$. Yahya'nın, yönetici Herod ailesinden kaynaklı zulmü ve ahlaksızları Allah'ın egemenliğine karşıt bir tutum olarak gördüğüne ve bu

16 Başta Kur'an olmak üzere İslami kaynaklarda, tüm peygamberler gibi Hz. Yahya ve Hz. İsa'nın temsil ve tebliğ ettiği temel mesaj tevhid akidesidir. Allah'tan başka hiçbir ilah edinmeme, O'na hiçbir şeyi ortak koşmama ve yalnızca O'na ibadet etme bu mesajın özünü oluşturur. 
nedenle bunları şiddetle eleştirmiş olduğuna dikkat çeker. Bu eleştirilerden hayli rahatsız olan Herod hanedanı sonunda Hz. Yahya'yı önce tutuklayarak sonra da başını kesmek suretiyle katlederek onun eleştirilerinden kurtulmaya çalışmıştır. ${ }^{17}$

Benzer şekilde Hz. İsa da toplumdaki egemen sınıfın ahlaksızlıklarına ve ikiyüzlülüklerine şiddetle eleştiri getirmiştir. Özellikle toplumdaki elitistlerin hukukun işleyişi de dâhil hemen her hususu kendi çıkar ve menfaatleri doğrultusunda yorumlayıp uygulamalarına, ikircikli tutum ve tavırlarına ciddi eleştiriler getirmiş ve onları "engerekler soyu”, "ikiyüzlüler" ve "kan içiciler" olarak nitelemiştir. ${ }^{18} \mathrm{~Hz}$. İsa'nın bu şiddetli eleştirileri başta tapınak yöneticileri olmak üzere zamanın egemenlerini rahatsız etmiş ve sonunda onu tutuklayıp ölüm cezasıyla yargılamışlardır.

Hıristiyan kaynaklarındaki bu verilere bakılırsa Hz. İsa'ya yapılan suçlama esas itibarıyla siyasidir; zira Hz. İsa egemen siyasal yapıya ve bunun temsilcilerine karşı çıkmaktadır. "İsrail'in kralı Mesih" olduğu iddiası ona yapılan siyasal temelli suçlamadır. ${ }^{19}$ Zira Kral-Mesih, Yahudi inancında sosyal, siyasal ve askeri bir değişimdönüşüm yapacak olan liderdir. Onun, geldiğinde zulme, inançsızlığa savaş açacağına, İsrailoğullarını yeniden bir birlik halinde toplayacağına, kötülere, İsrailoğullarının düşmanlarına karşı mücadele edeceğine ve onları yeniden arz-1 mev'udda muzaffer hale getireceğine inanılmaktadır.

İslam da tarih boyu gönderilen bütün peygamberlerin egemen sınıfın zulmüne, toplumda oluşturdukları fitne ve fesat düzenine karşı çıktıklarını, onların ulûhiyet ve rubûbiyet iddialarını reddettiklerini vurgular. Bu nedenle de peygamberlere ve inananlara karşı en şiddetli mücadeleyi öncelikle toplumdaki egemen sınıf ve onlar etrafında kümelenen ekâbir taifesi (mele') vermiştir. Örneğin içinde yaşadığı toplumda şirke ve küfre dayalı din anlayışına karşı çıkan ve halkı tevhid inancına davet eden Hz. İbrahim'e babası da dâhil şiddetle karşı çıkılmıştır. Hz. İbrahim, içinde yaşadığı toplumun cahiliye inancına karşı çıkmış, bu konuda halkı düşündürmek amacıyla toplumda yönetici erkin kendi düzenini onlar üzerinden meşrulaştırmaya çalıştıkları putları parçalamış, sahip olduğu güç ve servetten dolayı adeta iktidar sarhoşu olmuş olan yönetici taifesiyle

\footnotetext{
Bkn. Markos 1:1-6; Matta 3:1-10, 14:3-11.

Bkn. Matta 15:14, 23:16-19; Luka 6:39.

Bkn. Markos 15:16-32;
} 
mücadele etmiştir. Peygamberin faaliyetlerinden rahatsızlık duyup onu ve tebliğ ettiği öğretileri kendi egemenliklerindeki yapı için ciddi bir tehdit olarak görenler, sonunda onun ateşe atılarak yok edilmesine karar vermişler, ancak Allah onların planlarını boşa çıkarmıştır.

Allah, kendisine hükümdarlık verdi diye (şımarıp böbürlenerek) Rabbi hakkında İbrahim ile tartışanı görmedin mi? Hani İbrahim, "benim Rabbim diriltir, öldürür." demiş; o da "ben de diriltir, öldürürüm" demişti. (Bunun üzerine) İbrahim, "şüphesiz Allah güneşi doğudan getirir, sen de onu batıdan getir" deyince, kâfir şaşırıp kaldı. Zaten Allah, zalimler topluluğunu hidayete erdirmez (Bakara, 258).

"Eğer (bir şey) yapacaksanız, onu yakın da ilahlarınıza yardım edin" dediler. "Ey ateş! İbrahim'e karşı serin ve esenlik ol" dedik (Enbiya, 69).

Benzer şekilde Hz. Musa da Firavun'un küfre ve zulme dayalı yönetimine ve temsil ettiği dine karşı çıkmış ve onunla mücadele etmiştir. Hz. İbrahim'e olduğu gibi, Hz. Musa'ya ve ona iman edenlere karşı Firavun'un tutumu da benzer olmuştur; Firavun, Hz. Musa'nın tebliğ ettiği dine iman edenleri ellerini ve ayaklarını keserek cezalandırma yoluna gitmiştir. ${ }^{20}$

Kur'an, yönetici taife ve etraflarını çevreleyen ileri gelenler s1nıfının peygamberlere muhalefette her yola başvurduğunun altını çizer. Öyle ki malı, mülkü, serveti ve gücü ellerinde tutan bu kesim, sahip oldukları statüyü korumak ve şirke ve zulme dayalı geleneksel yapıyı sürdürmek amacıyla bu zulüm düzenine karşı çıkan peygamberleri sapkınlıkla, akılsızlıkla, yalancılıkla, bozgunculukla ve sihir yoluyla insanları etkilemekle suçlamışlardır. Ayrıca birbirlerini peygambere ve ona inananlara karşı kışkırtmışlar, peygamberi ve inananları yurtlarından kovmakla tehdit etmişlerdir. ${ }^{21}$ Örneğin Hz. Nuh, kavminin önde gelenlerinin şiddetli muhalefetiyle karşılaşmıs, onlar Hz. Nuh'u yalancılıkla, ona inananları da sefih kimseler olmakla itham etmişler ve bu sefihleri yanından kovmasını istemişlerdir. ${ }^{22}$ Toplumda serveti, gücü elinde tutan bu kesimin peygamberlere muhalefetinin arka planında peygamberin ve temsil ettiği dinin, güçlüler lehine yürürlükte olan sosyal ve siyasal sisteme

$20 \quad$ Bk. A'râf, 124, Tâhâ, 71

21 Örneğin bkn. A'râf, 60, 66, 75, 88, 90; Müminun, 33.

22 Bk. Hud, 27-31. 
karşı muhalefeti vardır. Nitekim bu nedenledir ki Hz. Nuh, Hz. Musa ve Hz. Harun'la ilgili ithamlarında görüldüğü gibi, peygamberlere toplumda bir "üstünlük elde etme" suçlaması yöneltmişlerdir.

Dediler ki: "Bizi atalarımızı üzerinde bulduğumuz yoldan döndüresin de yeryüzünde hâkimiyet (devlet) ikinizin eline geçsin diye mi bize geldin? Biz ikinize de inanmiyoruz" ${ }^{23}$ (Yunus, 78).

Bununla onlar, peygamberleri ve temsil ettikleri mesaj1, toplumsal yapıda sahip oldukları statüye karşı bir tehdit olarak görmüşler ve kendi zulüm sistemlerinin sorgulanacağı ve sahip oldukları gücü kaybedecekleri korkusuyla halka, peygamberlerin amacının kendileri yerine bu statüye konmak olduğu yönünde bir manipülasyon yapmışlardır. Bu durumda, peygamberler ve inananlarca temsil ve tebliğ edilen hakikat doğrultusunda, toplumsal yapıyı değiştirmek ve dönüştürmek çabasına, kendi varlıklarını, çıkarlarını ve menfaatlerini bu yapının devamında gören yöneticiler ve diğer ileri gelenler öncelikle karşı çıkmışlardır. Bu nedenle de peygamberlere karşı şiddetle muhalefet yürütmüşler, halkı da bu konuda maniple etmişlerdir.

Yukarıda incelediğimiz şekilde dini geleneklerde muhalefet kavramı önem arz etmekle birlikte, dini geleneklerde eleştirinin ve muhalefetin biçimi ve şekli konusunda da bir takım farklılığın olduğu bilinmektedir. Öyle ki dinsel geleneğin yapısına ve toplumsal konumuna göre muhalefet tarzı ve yöntemi değişiklik gösterir. Genellikle azınlık konumunda olan bazı geleneklerle sır dinleri şeklindeki yapılarda kendini gizlemeye dayalı takiyye geleneği ağır basar. Böylesi yapılarda muhalefet genelde metaforik/sembolik bir bağlamdadır. Benzer şekilde Gnostik geleneklerin muhalefet tarzında da metaforlar ağırlıktadır. Bu muhalefet tarzında otoriter egemen güçlere doğrudan bir muhalefet yerine din dilinde sembollerle ifade edilen eleştirel bir üslup hâkimdir. Örneğin içinde yaşadıkları toplumsal yapılarda egemen geleneklerin baskısı altında olan Gnostik akımlar, egemen çevreye ve egemenlere yönelik olarak din dilinde "yeryüzü hapishanesi" ve "arkonlar" gibi metaforik kavramlar geliştirmişlerdir. Buna göre onlar, içinde yaşadıkları maddi evrenin, kötü yöneticilerin ya da arkonların yönetiminde olduğu düşünülen

23 “Bunun üzerine kendi kavminden inkâr eden ileri gelenler şöyle dediler: "Bu ancak sizin gibi bir beşerdir, size üstünlük taslamak istiyor. ..." Müminun, 24. 
aslında geniş bir hapishaneden ibaret olduğu kanaatindedirler. Bu kanaat, her ne kadar teolojik değerlendirmelerle izah edilse de aslında toplumda marjinal heterodoksal akımları temsil eden Gnostik grupların, içinde yaşadıkları toplumdaki sosyal konumlarına işaret etmektedir. Zira çoğunlukça ya da egemenlerce temsil edilen ana gövde grupların baskıcı ve şiddet yanlısı tavırları karşısında Gnostikler, adeta bir hapishane hayatı yaşamaktadırlar.

Gnostisizm'e göre yeryüzü, bu kozmik hapishanenin en derin zindanı, ${ }^{24}$ 1şık varlıkları ya da ruhlar (ki bunlar Gnostik bireyleri ifade etmektedirler) ise mahkûmlarıdırlar. Gnostik kozmoloji kozmik hapishaneyi, yer altı âlemi, yeryüzü ve yeryüzünü çevreleyip kuşatan gezegenlerle burçlardan oluşan üç katmanlı bir mekân olarak düşünür. Yer altı âlemi, kötü varlıkların ve güçlerin yaşadıkları âlemdir; yeryüzü ise bunlarca ele geçirilen 1şık ruhlarının tutsaklıklarının devam ettiği, iyi-kötü mücadelesinin aktif olarak sürdüğü mekândır. Yeryüzü hapishanesini çevreleyen gezegenler ve burçlar ise birer gardiyan ya da muhafız olarak değerlendirilir. Gnostik literatürde sayıları 7 ilâ 365 arasında değişen bu kozmik kürelerde kötü yöneticiler olan arkonlar oturur. Arkonlar, bir çeşit evrensel kader olan tiranik yönetimleriyle tutsak ruhların köleliğini devam ettirmeye ve onları elden kaçırmamaya çalışırlar. ${ }^{25}$ Matarta ya da matarata olarak da adlandırılan bu gök cisimleri, aynı zamanda, yeryüzü hapishanesinden kurtulan ruhun ilahi özgürlük âlemine yükseliş yolunda geçmeleri gereken zorlu geçitler olarak da düşünülür.

Gnostisizm'in bu hapishane anlayışı, Gnostiklerin kendi içinde yaşadıkları sosyal siyasal yapıyı yansıtmaktadır. Tarih boyu Gnostik grupların içinde yaşadıkları toplumlarda marjinal akımlar olarak kaldıkları ve ortodoksiyi oluşturan çoğunluk anlayışlarca heretisizm ve sapkınlıkla suçlandıkları bilinmektedir. Kurtarıcı gizli bilgi/hikmet anlayışları, seçkin toplum olduklarına dair ürettikleri köken mitosları, ezoterik/dışa kapalı cemaat yapıları ve ritüelleri ve sosyal yapı ve geleneğe isyan olarak nitelenen asketik anlayışları nedeniyle Gnostikler, her zaman, yaşadıkları toplumlarda başkaldırı kültürünün temsilcileri olan ötekiler olarak görülmüşler, sihirbazlık ve büyücülükle suçlanmışlar, toplumsal değer ve kurumlara karşı

24 H. Jonas, The Gnostic Religion, Beacon Hill, 1958, s. 43. 
suç odağı olmakla itham edilmişler ve sık sık takibata uğramışlardir.

Çeşitli erken dönem Hıristiyan Gnostik akımlarının metinlerinde, sembolik bir dille arkonlar olarak adlandırılan maddi evrenin hegemonyal güçleri, tutsak ettikleri varlıkları, yani Gnostikleri, sürekli bir gözetim altında tutmaya çalışmakta, bu nedenle Gnostiklerin dışa kapalı cemaat yapılarıyla ezoterik inanç ve ritüellerinden hoşlanmamaktadırlar. Onların amacı, Gnostiklerin kendi ellerinden kurtulup kaçmalarını engellemektir. Zira bu sosyal-siyasal düzenin ve evrende devam edegelen saltanatlarının sürmesi bu tutsaklığın devamına bağlıdır. Gnostik geleneklerdeki bu evren hapishanesi metaforunda Gnostikler, kendilerini kuşatmış olan ve kötülüğü ifade eden toplumsal yapıyı bir hapishane, 1şık varlıkları ile özdeşleştirdikleri kendilerini birer tutsak ve karanlık yöneticiler/güçler ya da arkonlar olarak adlandırdıkları güçleri ise özgürlüklerini engelleyen gardiyanlar olarak değerlendirmektedirler.

Dinsel muhalefet, Gnostik gelenekler üzerinden örneklendiği gibi her dinde sembolik metaforik bir bağlamda dile getirilmez. Kur'an'da öngörüldüğü gibi, hakkın temsilinin ve batıla, yanlışa karşı muhalefetin eğip bükmeden olması gerektiğini vurgulayan bir tarz da vardır. Her ne kadar genelde günümüzde İslam kültürü içerisinde egemen güçlere ve onlar tarafından yönlendirilen sosyal, siyasal yapılara itaate dayalı bir kültür cari olsa da İslam esasta Müslüman bireyi ve toplumu her türlü ifsada, zulme ve Allah'a isyana karşı çıkmaya yönlendirmektedir. Hakkı temsil etmede ve batıla ve yanlışa karşı muhalefette açık sözlü olmayı, hakikati eğip bükmeden temsil etmeyi ve özüyle ve sözüyle onurlu bir duruş sergilemeyi öngörmektedir.

Öyle ise adaleti yerine getirmede nefsinize uymayın. Eğer çarpıtırsanız veya çekinirseniz (bilin ki) şüphesiz Allah yaptıklarınızdan hakkıyla haberdardır (Nisa, 135).

İslam'ın öngördüğü bu duruş, öncelikle kişinin safını belirlemesi, haktan ve hakikatten yana tavır alması ve sonra da batıla karşı olması gerektiği şekilde mücadele etmesidir.

Peygamberlerin yaşamindan verdiği örneklerle Kur'an, Müslümanlara bu onurlu ve ilkeli muhalif tavrın ipuçlarını verir. Bunlardan birisi, Müslüman bireylerin dosdoğru yol olan Allah'ın yolundan ayrılmamaları, başka yollara tevessül etmemeleri ya da onlardan medet ummamalarıdır: 
İşte bu, benim dosdoğru yolum. Artık ona uyun. Başka yollara uymayın. Yoksa o yollar sizi parça parça edip O'nun yolundan ayırır. İşte size bunları Allah sakınasınız diye emretti (En'am, 153).

Bir diğeri ise, içinde yaşadıkları toplumsal yapıda inananların saflarını ayırmaları gerekliliğidir. Peygamberler ve onlara iman edenler içinde yaşadıkları toplumun sapkınlıklarıyla aralarına kesin bir mesafe koymuşlar ve saflarını ayırmışlardır:

İbrahim'de ve onunla birlikte bulunanlarda sizin için güzel bir örnek vardır. Hani onlar kavimlerine, "Biz sizden ve Allah'ı bırakıp taptıklarınızdan uzağız. Sizi tanımıyoruz. Siz bir tek Allah'a inanıncaya kadar, sizinle bizim aramızda sürekli bir düşmanlık ve nefret belirmiştir" demişlerdi (Mümtehine, 4).

Bir diğer ipucu ise inanılan değerlerden asla taviz verilmemesi, hak ve hakikatin pazarlık konusu yapılmamasıdır. Bu nedenledir ki peygamberler zaman zaman toplumsal statüleri öne çıkarılarak sorgulanmaya çalışılmıştır. Örneğin Hz. Salih'in toplum içinde ümit beslenen birisi olduğuna dikkat çekilmesi gibi:

Onlar şöyle dediler: “Ey Salih! Bundan önce sen, aramızda ümit beslenen bir kimseydin. Şimdi babalarımızın taptıklarına tapmamızı bize yasaklıyor musun? Şüphesiz, biz senin bizi çağırdığın şeyden derin bir şüphe içindeyiz" (Hud, 62).

\section{Netice}

Sonuç olarak din, insanın inandığı yüce varlıkla ve değerlerle ilişkisinde itaat ve ittibâ kavramlarını esas alır. Allah'a muhalefeti sapkınlık, küfür, şirk ve zulüm olarak görür. Dünyevi iktidarlar ve otoriteyle ilgili her dini gelenek kendi egemenlik/iktidar anlayışından hareketle bir perspektif ortaya koyar. Bir değer olarak otoriteyi kutsayan ve bu nedenle her otoriteryan yapıyı meşru gören gelenekler, dünyevi otoritelere meşruiyet kazandırıp bunlara mutlak itaati öngörürken, bazıları ise egemenliğin mutlak anlamda Tanrı'da olduğunu ve ancak Tanrı'ya mutlak anlamda itaat edileceğini vurgular.

Dünyevi yönetimlerle ilişkiler konusunda İslam, referansını Allah'tan, Allah'ın öngördüğü sınırlardan almayan her yapıya karşı çıkar; her konuda egemenliğin ve üstünlüğün mutlak sahibinin ancak Allah olduğunun altını çizer. Allah'ın koyduğu kuralları dışlayan her yönetimin ve sistemin sadece zulüm, fesat ve şirk 
üreteceğini belirtir. Böylesi yapılara muhalefet edip karşı çıkmayı ise bir sorumluluk olarak görür. Kur'an, tarihsel süreçte tüm peygamberlerin içinde yaşadıkları böylesi yapılarla mücadele edip, küfre, şirke ve zulme muhalefet ettiklerini vurgular. Hakikati gizlemeyen, eğip bükmeyen ve zalimlere meydan okuyan bir duruşla bir mücadele verdiklerini ve bu uğurda her türlü baskıya, tehdide ve takibata göğüs gerdiklerine dikkat çeker.

\section{Kaynakça}

Basalel, Yusuf. Yahudilik Ansiklopedisi, İstanbul: Gözlem, 2001, c. 1.

Canfora, Luciana. Julius Caesar: The Life and Times of the People's Dictator, University of California Press 2007.

Cullmann, Oscar. The Early Church, London: SCM Press, 1956.

Helms, Randel. Gospel Fictions, New York: Prometheus Books, 1988.

Hillerbrand, Hans J. A New History of Christianity, Abingdon Press, 2012.

Hinson, E. Glenn. "Constantinianism", Encyclopedia of Religion, (second edition), ed. L. Jones, Thomson Gale 2005, c. 3.

Horsley, Richard A. (ed.), Paul and Empire, Religion and Power in Roman Imperial Society, Trinity Press International, 1997.

Jonas, H. The Gnostic Religion, Beacon Hill ,1958.

Mortimer, Edward. Faith and Power: The Politics of Islam, London: Faber and Faber, 1982.

Najovits, Simson R. Egypt, Trunk of the Tree: A Modern Survey of and Ancient Land, vol. I:, Algora Publ., 2003. 